\title{
Measurement of Frictional Pressure Differentials During a Ventilation
}

\section{Survey}

\author{
Brian S. Prosser, PE \\ Bechtel SAIC Company \\ Ian M. Loomis, $\mathrm{PE}, \mathrm{PhD}$ \\ Mine Ventilation Services, Inc.
}

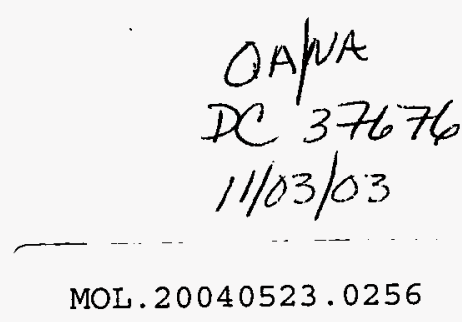

\begin{abstract}
During the course of a ventilation survey, both airflow quantity and frictional pressure losses are measured and quantified. The measurement of airflow has been extensively studied as the vast majority of ventilation standards/regulations are tied to airflow quantity or velocity. However, during the conduct of a ventilation survey, measurement of airflow only represents half of the necessary parameters required to directly calculate the airway resistance. The measurement of frictional pressure loss is an often misunderstood and misapplied part of the ventilation survey. This paper compares the two basic methods of frictional pressure drop measurements; the barometer and the gauge and tube. Personal experiences with each method will be detailed along with the authors' opinions regarding the applicability and conditions favoring each method.
\end{abstract}

\section{INRODUCTION}

The quantification of differential pressures and airflows is essential for the development of an accurate ventilation model. An emphasis has always been placed on the measurement of airflow as it is required for the fulfillment of most governmental ventilation regulations. Various techniques and instruments have been developed to provide accurate airflow measurements; (averaged spot measurements, anemometer traverses, ultrasonic measurements, pitot tube measurements, vane anemometers, hotwire anemometers, velometers, and vortex shedding anemometers) and they have been studied extensively in symposium papers and doctorial theses. However, as the measurement of frictional pressure drops is generally required only for the quantification of airway resistance and is not required in the day to day operation of a mine very little is actually studied about this method. Most all mining references contain an obligatory section on pressure measurement (typically detailing fan measurements), however, there are few texts that actually detail the practicalities involved with the conduction of a pressure survey.

\section{GENERALITIES}

In general there are two practical methods that can be used to determine the pressure differentials in a mine; barometer (altimeter) survey, and gauge/tube survey. Each survey technique has its place, is accurate under certain circumstances, and each should be incorporated into the ventilation survey but only under specific circumstances.

The use of barometers (altimeters) in ventilation surveys has long been established and various techniques have been developed to incorporate their readings into the structure of a ventilation survey. However, with improvements in micromanometers and for reasons discussed in the following section the usefulness of the barometer is limited to measurement of shafts, across inaccessible areas, or areas of high pressure differential. The continuous improvement of micromanometers over time has improved the accuracy and convenience of differential pressure measurement across bulkheads and ventilation structures as well as increased the accuracy of measurements in areas of lower frictional pressure drops. Although a barometric survey can be accomplished by a single person taking measurements at specific locations and a manometer survey requires a team of at least two people, the increased accuracy of the manometer survey will more than make up for the utilization of added personnel. If the decision is made to conduct a ventilation survey, then that survey should be conducted in a manner so as to provide the most accurate and useful information possible relative to the intended purposes of the data. The degree of 
accuracy of the data should be determined prior to the selection of the survey method.

\section{BAROMETER SURVEY}

There are two basic types of barometer surveys; roving, and leapfrogging. The roving method can be accomplished by a single person as long as a recording surface barometer is used. This method involves continuously or incrementally recording a stationary "surface" barometer along with the roving barometric pressure at points in the mine. The barometric pressure at each point can then be corrected for changes in the background pressure over the course of the shift by using the surface barometer reading. This method assumes that the barometric pressure in the mine will fluctuate at exactly the same time as the fluctuation is noted on surface. This assumption and inherent weakness can be mitigated by using the "leapfrog" technique. This method involves two measurement teams recording the barometric pressure simultaneously at two points underground. A surface barometer is not needed as the measurements are taken simultaneously. This method is inherently more accurate but requires constant communication between the measurement teams which is not always present in an adequate form in many mining operations.

In general the barometer should be placed in approximately the same spatial location within the drift for each measurement, either the center of the drift, near the rib, etc. This will allow the turbulence conditions to be relative constant for each measurement. Individual measurements taken in areas of high turbulence (in the midst three or four way intersections) should be avoided as the measurement could be improperly influenced. Regardless of which method is used there is a substantial amount of data reduction involved in the determination of the pressure differential between two points when the barometric method is used. Differential pressures across bulkheads, doors, and fans should still be measured with a manometer. These measurements are used to tie the differential pressures measured along the airways by the barometers together to ensure accuracy. Depending upon the method used for the reduction of the barometric pressure data, psychrometric data is required to be measured at each measurement location along with the barometric pressure. The accuracy of the psychrometric data should be held to as high a standard as possible as the errors in the psychrometric measurements and barometric pressures will have a compounding effect.

\section{THEORETICAL REDUCTION OF BAROMETRIC SURVEY DATA}

Three different methods were used to determine the frictional pressure differential in this section. For this example the frictional pressure differential in a shaft is determined. The roving method is used and the following data presented in Table 1 was measured.

\begin{tabular}{|l|c|c|c|c|c|c|}
\hline \multicolumn{1}{|c|}{ Location } & $\begin{array}{c}\text { Surface } \\
\text { Barometer } \\
(\mathrm{kPa})\end{array}$ & $\begin{array}{c}\text { Roving } \\
\text { Barometer } \\
(\mathrm{kPa})\end{array}$ & $\begin{array}{c}\text { Dy Bulb } \\
\text { Temp. } \\
\left({ }^{\circ} \mathrm{C}\right)\end{array}$ & $\begin{array}{c}\text { Relative } \\
\text { Humidity } \\
(\%)\end{array}$ & $\begin{array}{c}\text { Air } \\
\text { Velocity } \\
(\mathrm{ft} / \mathrm{min})\end{array}$ & $\begin{array}{c}\text { Elevation } \\
(\mathrm{m})^{2}\end{array}$ \\
\hline Top of Shaft & 98.782 & 103.750 & 15.6 & 13.0 & 400 & 2652.0 \\
\hline $\begin{array}{l}\text { Bottom of } \\
\text { Shaft }\end{array}$ & 98.800 & 104.610 & 17.2 & 14.2 & 299 & 2573.0 \\
\hline
\end{tabular}

Davis Anemometer calibrated in feet, converted to $\mathrm{SI}(\mathrm{m} / \mathrm{s})$ in spreadsheet presented below

Elevation given by site surveyors and measured independently of ventilation survey

Table 1: Barometer Survey Data Reduction

\subsection{Method 1: Direct Application of the Steady Flow Energy Equation}

Subsurface Ventilation and Environmental Engineering (McPherson 1993, Section 6.3) provides the following procedure for reduction of the data taken during a barometric pressure survey. Equation 1 (Steady Flow Energy Equation) is used evaluate the work done against friction as the air travels between two stations.

$F_{12}=\frac{u_{1}^{2}-u_{2}^{2}}{2}+\left(Z_{1}-Z_{2}\right) g-R\left(T_{2}-T_{1}\right) \frac{\ln \left(P_{2} / P_{1}\right)}{\ln \left(T_{2} / T_{1}\right)}$

Where:F - Work done against friction $(\mathrm{J} / \mathrm{kg})$

$\mathrm{P}$ - Barometric pressure $(\mathrm{kPa})$

$T$ - Absolute temperature (Kelvin)

$\mathrm{Z}$ - Elevation of barometer location (m)

$\mathrm{u}$ - Air velocity at the barometer location $(\mathrm{m} / \mathrm{s})$

$\mathrm{R}$ - Mean gas constant $(\mathrm{J} / \mathrm{kg} \mathrm{K})$

$\mathrm{g}$ - Gravitational acceleration $\left(9.81 \mathrm{~m} / \mathrm{s}^{2}\right)$

This work term is then converted into a frictional pressure drop using Equation 2.

$\mathrm{p}_{12}=\rho_{\mathrm{a}} \mathrm{F}_{12}$

Where: $p_{12}$ - Frictional pressure drop (Pa)

$\rho_{a}$ - Average density of air between two stations $\left(\mathrm{kg} / \mathrm{m}^{3}\right)$

If the two stations are not read simultaneously it is necessary to apply a correction to one of the values to incorporate any changes in the surface atmospheric pressure. By assuming that a series of polytrophic processes link the control barometer to the roving unit underground, then the following correction is applied as described by Equation 3 . 
$\mathrm{P}_{1}^{\cdot}=\Delta \mathrm{P}_{\mathrm{c}} \frac{\mathrm{P}_{\mathrm{I}}}{\mathrm{P}_{\mathrm{c}}}$

Where: $P_{1}$ - Updated value for barometric pressure at station 1

$P_{1}$ - Raw data for barometric pressure at station 1

$\Delta \mathrm{P}_{\mathrm{c}}$ - Change in surface atmospheric pressure

$P_{c}$ - Surface atmospheric pressure taken at the same time as station 1 reading

\subsection{Method 2: Approach Recommended by the Mine Ventilation Society of South Africa (MVSSA)}

Environmental Engineering in South African Mines (Burrows J. et al 1989, Chapter 6) uses the following approach outlined in Equations 4 and 5 to determine the pressure loss:

$p_{12}=-\left(P_{2}-P_{1}\right)-g \int w d Z$

Where the term $g \int w d Z$ is the theoretical increase in pressure. The difficulty with this approach is in evaluating the integral term for the change in air density as a function of depth. A series of stations could be established between the points, however this can result in an excessive amount of data reduction. Hence, an assumption is made that the density varies linearly with elevation, as given in Equation 5:

$$
\int w d Z=\frac{1}{2}\left(\rho_{1}+\rho_{2}\right)\left(Z_{1}-Z_{2}\right)
$$

The error associated with this assumption is particularly severe when the elevation change is large. For elevation changes of less than $300 \mathrm{~m}$ the equations are considered adequate. Another assumption with this method is that the airflow present at each station is representative of the airway in between. This is valid in certain cases, but is obviously not correct when complex networks are involved.

\subsection{Method 3: Exact Density Solution - Per Hall (1981)}

Mine Ventilation Engineering (Hall C.J. 1981, Chapter 8) presents an exact solution for barometric pressure data that uses a density analysis (similar to the MVSSA method presented above). In this case a frictionless pressure $\left(\mathrm{P}_{2 \text { calc }}\right)$ is determined from Equation 6.

$P_{2 \text { calc }}=P_{2}\left(\frac{2 P_{1}+D g \rho_{1}}{2 P_{2}-D g \rho_{2}}\right)$

Where: D - Depth below datum (m)
The pressure drop due to friction, shock and increases in kinetic energy is given by the following equation:

$\mathrm{p}_{12}=\mathrm{P}_{2 \text { calc }}-\mathrm{P}_{2}$

\subsection{Comparison of Data Reduction Methods}

As can be seen from the calculations below (Table 2, Table 3, and Table 4), all three methods provide very similar answers. The method recommended by Dr. McPherson results in a value of $127 \mathrm{~Pa}$, compared to 129 and $130 \mathrm{~Pa}$ for the MVSSA and Hall respectively. However, this difference is very small, and provided that the difference in elevation is not too great, each of these methods is acceptable for reducing survey data.

\begin{tabular}{|c|c|c|c|c|c|c|c|}
\hline \multicolumn{8}{|c|}{ Input Data Shect for Barometric Survcy - Wet Bulb/Dry Bulb Input } \\
\hline \multirow{2}{*}{$\begin{array}{l}\text { Station } \\
\text { Number }\end{array}$} & \multirow[t]{2}{*}{ Time } & \multirow{2}{*}{$\begin{array}{c}\text { Traverse } \\
\text { Barometer } \\
\mathrm{P} \text { (mbar) }\end{array}$} & \multicolumn{2}{|c|}{ Temperatures } & \multirow{2}{*}{$\begin{array}{c}\text { Elevalion } \\
\mathrm{Z} \\
\text { (m) }\end{array}$} & \multirow{2}{*}{$\begin{array}{c}\text { Velocity } \\
u \\
\text { (fpm) }\end{array}$} & \multirow{2}{*}{$\begin{array}{c}\text { Control } \\
\text { Barometer } \\
\text { (mbar) }\end{array}$} \\
\hline & & & $\begin{array}{l}\text { Id } \\
\text { (C) }\end{array}$ & $\begin{array}{l}\text { Iw } \\
\text { (C) }\end{array}$ & & & \\
\hline$\overline{1}$ & $13: 42$ & 1037.50 & 15.60 & 13.00 & 2652.0 & 400.0 & 987.8 \\
\hline 2 & $14: 05$ & 1046.10 & 17.20 & 14.20 & 2573.0 & 299.0 & 988.0 \\
\hline \multicolumn{8}{|c|}{$\begin{array}{l}\text { Calculated Data } \\
\text { e to the right for mo }\end{array}$} \\
\hline $\begin{array}{l}\text { RH } \\
\text { Calc } \\
(\%)\end{array}$ & $\begin{array}{l}\text { Actual } \\
\text { Density } \\
(\mathbf{k g} / \mathrm{m} 3) \\
\end{array}$ & $\begin{array}{c}\text { Gas } \\
\text { Constant } \\
(\mathrm{J} / \mathrm{kgC})\end{array}$ & \begin{tabular}{|c|} 
Diff \\
Pressure \\
(Pa)
\end{tabular} & $\begin{array}{c}\text { Corrected } \\
\text { Pressure* } \\
\text { (kPa) }\end{array}$ & \begin{tabular}{|c|} 
Work \\
Done 1-2 \\
$(\mathrm{J} / \mathrm{kg})$
\end{tabular} & $\begin{array}{c}\text { Pressure } \\
\text { Drop 1-2 } \\
(\mathrm{Pa}) \\
\end{array}$ & $\begin{array}{c}\text { Press Dr. } \\
\text { British } \\
\text { (m. in. w.g.) }\end{array}$ \\
\hline $\begin{array}{l}74.7 \\
72.2\end{array}$ & $\begin{array}{l}1.246 \\
1.249\end{array}$ & $\begin{array}{l}288.431 \\
288.517\end{array}$ & 0.018 & $\begin{array}{l}103.769 \\
104.610\end{array}$ & 101.60 & 127 & $\begin{array}{c}- \\
5018.75\end{array}$ \\
\hline $\begin{array}{l}\text { Sal Vap } \\
\text { csw } \\
(\mathrm{Pa}) \\
\end{array}$ & $\begin{array}{c}\text { Moist Sat } \\
\text { Xs } \\
(\mathrm{kg} / \mathrm{kg} \text { Dry })\end{array}$ & $\begin{array}{c}\text { Latent } \\
\mathrm{Lw} \\
(\mathrm{J} / \mathrm{kg}) \\
\end{array}$ & \begin{tabular}{|c|} 
Sigma \\
S \\
(J/kg Dry)
\end{tabular} & \begin{tabular}{|c|} 
Moist Truc \\
X \\
(kg/kg Dry)
\end{tabular} & \begin{tabular}{|c|} 
Vap Press \\
$\mathrm{e}$ \\
$(\mathrm{Pa})$ \\
\end{tabular} & \begin{tabular}{|c|} 
Enthalpy \\
$\mathrm{h}$ \\
(J/kg Dry)
\end{tabular} & $\begin{array}{l}\text { Dry Vap } \\
\text { esd } \\
(\mathrm{Pa}) \\
\end{array}$ \\
\hline 1497.280 & 3) 0.009108 & 2471482 & 35575 & 0.008035 & 1323.106 & 36012.4 & 1771.767 \\
\hline 1618.941 & 0.009777 & 2468619 & 38408 & 0.008536 & 1416.258 & 38915.1 & 1961.783 \\
\hline
\end{tabular}

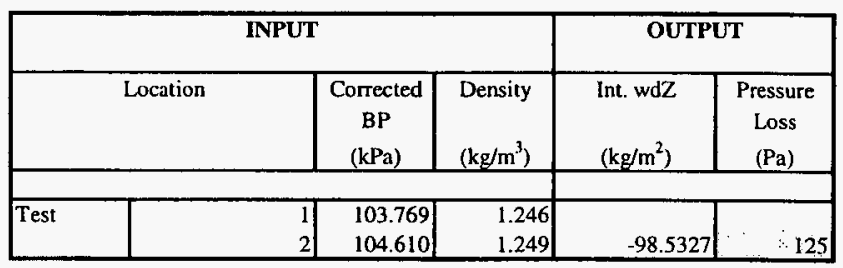

Table 3: Barometer Data Reduction After MVSSA (1989)

\begin{tabular}{|c|c|c|c|c|}
\hline \multicolumn{3}{|c|}{ INPUT } & \multicolumn{2}{|c|}{ OUTPUT } \\
\hline Location & $\begin{array}{c}\text { Corrected } \\
\text { BP } \\
(\mathrm{kPa})\end{array}$ & $\begin{array}{l}\text { Density } \\
\left(\mathrm{kg} / \mathrm{m}^{3}\right)\end{array}$ & $\begin{array}{l}\mathrm{P}_{\text {ocalc }} \\
(\mathrm{kPa})\end{array}$ & $\begin{array}{l}\text { Pressure Loss } \\
\text { (Pa) }\end{array}$ \\
\hline Test & $\begin{array}{l}103.769 \\
104.610\end{array}$ & $\begin{array}{l}1.246 \\
1.249\end{array}$ & 104.7358 & 126 \\
\hline
\end{tabular}

Table 4: Barometer Data Reduction After Hall (1981)

\subsection{Instrumentation}

There are four basic types of barometers used in mining. They can be classified into precision electronic barometer (Setra), reduced accuracy electronic barometer (Air Instruments), precision 
aneroid barometer (Wallace \& Tiernan), and reduced accuracy aneroid barometer (Taylor).

In general, the most accurate instrumentation should be used. The span encompassed by the resolution of reduced accuracy barometers in some cases is greater than the value of the frictional pressure drop attempted to be measured. The aneroid barometers have the advantage of being permissible and allowed into the return airways in coal mines, however they can be difficult to read/interpolate and take longer to stabilize than the electronic barometers. The electronic barometers have a finer resolution, foolproof digital readout, and rapid stabilization but are tied to a battery, and are somewhat fragile to the harsh atmospheric conditions experienced in mines. But under the controlled conditions of a ventilation survey and limited contact with the mining atmosphere the precision electronic barometers should be used in order to obtain the most accurate results. Although the Setra barometer has a significant weight, and is somewhat bulky, the increased accuracy of the measurement more than offsets the discomfort of carrying the instrument during the survey. In addition to the barometers, the instrument elevations must be surveyed accurately and the survey stations well marked. The psychrometric properties of the air must also be accurately quantified. A digital relative humidity/dry bulb temperature instrument can greatly speed up the measurement of psychrometric properties.

\section{GAUGE AND TUBE METHOD}

Frictional pressure drops through airways can accurately be determined using the gauge-and-tube technique. The gauge and tube (or trailing hose) method allows the direct measurement of frictional pressure differentials using a digital manometer (or magnehelic gauge) connected to a length of tubing, the ends of which are connected to the total pressure ports of pitotstatic tubes. Lengths of $1 / 4$ inch nylon tube of up to $1,000 \mathrm{ft}$ (limited by practicality) can be used. The nylon (strong, semi rigid, relatively inflexible) tube is strung along a drift from one marked station to another marked station. Both ends of the tube are connected to pitot tubes which are positioned facing into the airstream. A manometer is placed in-line as shown in Figure 1. In this way the difference in total pressure between the two stations can be measured. When the measurement is finished (the manometer has stabilized around an average value) the person at the rear of the tube is signaled (cap lamp or tug signal) and the tube is then advanced along the drift to the next measurement location, the person at the rear of the tube will halt at the next measurement station. The survey must be planned in advance to determine the most appropriate tube length, and approximate measurement station locations. In order to increase confidence in the measurement, the tube must be pressure tested prior to each shift to ensure against a leak. In general the rear tube measurement location should be up wind of the manometer, or positive side of the manometer. In this way the tube can be judged to be functioning properly by examining the response of the manometer. If the pressure displayed on the manometer shows no fluctuation from the previous measurement a kink is indicated, if it displays little to no pressure differential then a leak in the tube may be indicated. The pressure should build slowly from zero to the actual pressure differential and then oscillate around an average value. Although the manometer will rarely settle steadily on a value because of turbulence, it will stabilize around an average value.

Figure 1: Gauge and Tube Technique

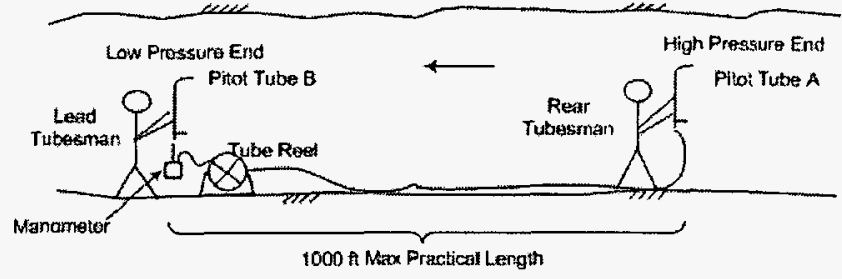

This measurement technique is independent of changes in elevation (to a certain extent explained a little further on), psychrometric parameters, or independent air velocity measurements. No further equipment other than the pitot tubes, nylon connection tube, and manometer need be used. The simplicity of the measurement allows for rapid reduction of data, field accuracy/verification checks, and is unhindered by the need for additional parameters to be measured by the survey team. However, this method requires at least two people for the measurement, and can be exceedingly difficult and cumbersome to use if improperly planned. Each airway must be measured from junction to junction which causes problems if too long or too short of a tube length is used. This method can and has been used to accurately measure frictional pressure drops down to 5 milli in. w.g.

Measurements taken in shafts or long ramp systems with significant changes in elevation may be subject to a correction factor. This correction factor is necessary as the air in the measurement tube is stationary, and not affected by friction, which will result in a slightly higher pressure inside of the tube than exists in the airway (McPherson 1993, Section 6.3.1). This correction can be approximated by Equation 8 (Hinsley 1962). 


$$
p_{12}=\Delta \mathrm{P} \times \frac{\mathrm{P}_{\mathrm{m}}}{\mathrm{P}_{\mathrm{L}}}
$$

Where: $p_{12}$ - Frictional pressure drop from point 1 to point 2

$P_{m}$ - Mean barometric pressure in the shaft

$P_{L}$ - Barometric pressure at measurement location (at either point 1 or point 2)

$\Delta \mathrm{P}$ - Raw differential pressure measurement

Shafts of up to $2,000 \mathrm{ft}$ in depth can be directly measured without the need for correction, however, the application of the correction factor should be used for shaft measurements over $2000 \mathrm{ft}$ in depth. The correction for elevation differences is insignificant for measurements taken along normal working levels in mines. For long ramp systems with significant changes in elevations a correction could be applicable if the entire ramp were to be measured with a single tube measurement, however, this is not practical. In practice ramps measurements are broken into many smaller segments and generally measured with tube lengths of less than $500 \mathrm{ft}$ to avoid excessive drag on the tube as it wraps around the various bends encountered in a ramp. Shafts of up to $2,000 \mathrm{ft}$ can be directly measured without the need for correction, however, much past that requires the application of the correction factor.

\subsection{Instrumentation}

The equipment used to measure the differential pressure must be accurate, incorporate a fine resolution, and be durable. Probably the best instrument for measuring the differential pressure along airways has been found to be the Zephyr pressure gauge, it incorporates a "damping" feature in the instrument, is self zeroing, fine resolution down to 0.001 in. w.g. $(0.1 \mathrm{~Pa})$, high accuracy, shock proof, and incorporates a water resistant case. But it is not permissible and cannot be used in coal mine exhaust airways. The Taylor manometer does not have the accuracy or resolution to measure the often low pressures encountered in along an airway, however it is an excellent device to measure differential pressures across bulkheads, regulators, and doors. The PDM 304 has the same problems as the Taylor with respect to accuracy and resolution, but it is the only permissible electronic manometer available that can be used in coal mine exhaust airways. The $1 / 4$ inch magnehelic gauge is the instrument originally used for this technique. It is an extremely sensitive mechanical pressure measurement device that can be used in any environment. However, it is extremely sensitive to horizontal alignment which makes field measurements with it extremely troublesome as a few degrees off level results in a widely varying measurement. An example of each instrument is shown in Figure 2. Inclined water or oil filled manometers really have no place during the performance of a modern ventilation survey. With the continual upgrade and development of electronic manometers the process of measuring pressure drops is greatly streamlined.

Figure 2: Manometers

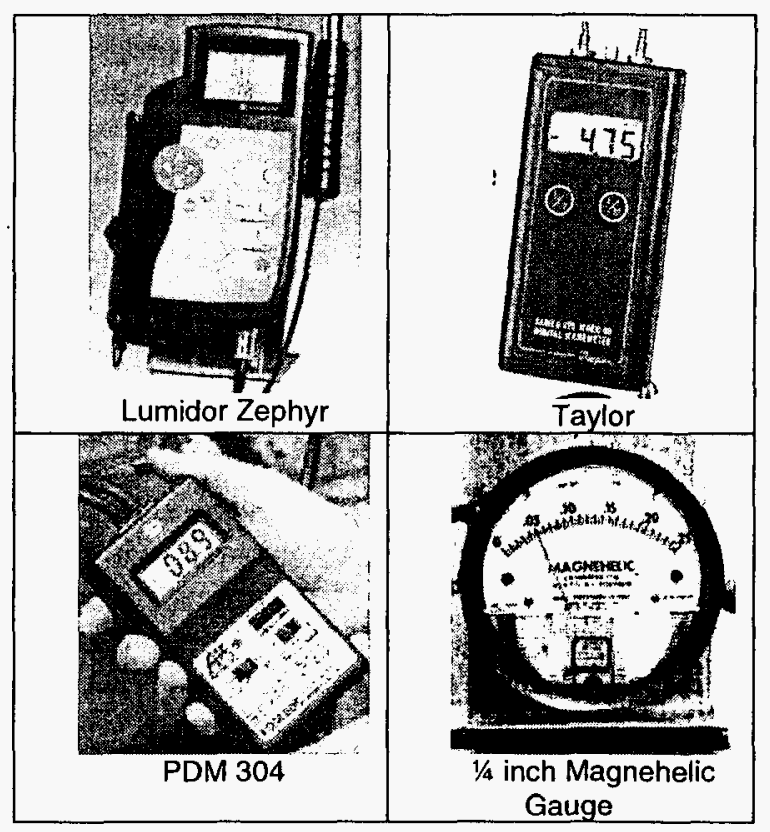

6 EXAMPLES OF PARALLEL MEASUREMENTS AND CASE STUDY MEASUREMENTS (EXAMPLES)

During a recent ventilation survey the frictional pressure drop was measured in a set of airways. The pressure differential was measured with both the gauge and tube, and barometer method in order to provide a set of checks. Figure 3 (not to scale) shows a schematic with the gauge and tube measurements taken during the ventilation survey and the measurement points for the barometer survey (points A through D). An effort was made to measure everything as accurately as possible within the time allotted for the measurements. The gauge and tube measurements took approximately $1 \frac{1}{2}$ shifts to complete, and the barometer measurements took approximately $1 / 2$ shift to complete. If the barometer measurements were accurate enough a substantial time savings could be realized in the field. 
Figure 3: Pressure Survey Measurements

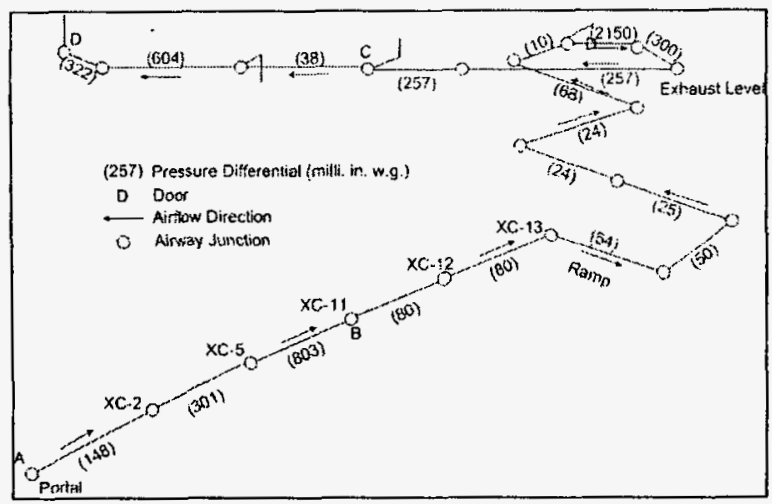

The application of the gauge and tube method during this survey involved extensive methods in ramps, along main haul routes, and through high velocity drifts. The direction of airflow along the path of this section of the survey was constant, although the airflow through the measured drifts increased and decreased at the various junctions. The gauge and tube measurements were broken at each junction where a significant amount of air entered or exited the measurement route. The gauge and tube measurements are summarized in Table 8.

The data obtained during the barometric portion of the ventilation survey are shown in Table 5 . Measurements of barometric pressure, dry bulb temperature, relative humidity, and air velocity were taken at each station shown on Figure 3. A control barometer was set up at the engineers office outside of the mine to measure changes in barometric pressure over time at a fixed location. The elevations of each barometric measurement station were provided by the mine survey department.

\begin{tabular}{|c|c|c|c|c|c|c|c|c|}
\hline \multicolumn{9}{|c|}{ BAROMETER SURVEY MEASUREMENT INPUT DATA } \\
\hline Locatior & & Time & $\begin{array}{c}\text { Traverse } \\
\text { Barometer } \\
\text { (kPa) }\end{array}$ & $\begin{array}{l}\text { Dry Bulb } \\
\text { Temperature } \\
\text { (C) }\end{array}$ & $\begin{array}{c}\text { Relative } \\
\text { Humidity } \\
(\%)\end{array}$ & $\begin{array}{l}\text { Velocity } \\
\text { (tiv/min) }\end{array}$ & $\begin{array}{c}\text { Elevation } \\
\text { (m) }\end{array}$ & $\begin{array}{c}\text { Control } \\
\text { Barometer } \\
\text { (kPa) }\end{array}$ \\
\hline From: & & $12: 04$ & & 13.0 & 77.7 & 0 & & \\
\hline & B & $11: 55$ & & & & 1304 & & \\
\hline From: & $\bar{B}$ & $11: 55$ & & 10.9 & 90.8 & 1304 & 3112.8 & $\overline{72.419}$ \\
\hline To: & c & 11:13 & & & & 215 & & \\
\hline From: & & $11: 13$ & 68.630 & 13.6 & 92.3 & 215 & 3197.7 & 72.437 \\
\hline To: & D & $11: 37$ & 3.518 & 13.1 & 97.0 & 1983 & 3239.6 & 72.437 \\
\hline From: & & $12: 04$ & 72.350 & 13.0 & 77.7 & 0 & 2946.0 & 72.391 \\
\hline To: & D & & & 13.1 & 97.0 & 1983 & & 72.437 \\
\hline
\end{tabular}

Table 5: Barometric Survey Measurement Data

Table 6 and Table 7 show the data reduction for these measurements.

\begin{tabular}{|c|c|c|c|c|c|c|c|c|}
\hline \multicolumn{9}{|c|}{ BAROMETER SURVEY DATA REDUCTION CALCULATIONS } \\
\hline Location & \begin{tabular}{|c|}
$\begin{array}{c}\text { Absolute } \\
\text { Temp } \\
\text { (K) }\end{array}$ \\
\end{tabular} & $\begin{array}{c}\text { Partial } \\
\text { Press. e } \\
\text { (Pa) }\end{array}$ & $\begin{array}{c}\text { Moisture } \\
\text { Content X } \\
\text { (kg/kg dry) }\end{array}$ & $\begin{array}{c}\text { Gas } \\
\text { Constant } \\
(\mathrm{J} / \mathrm{kg} \mathrm{C}) \\
\end{array}$ & $\begin{array}{c}\text { Mean Gas } \\
\text { Constant } \\
\text { (J/kg C) }\end{array}$ & $\begin{array}{l}\Delta \text { Sur } \\
\text { Press. } \\
\text { (kPa) }\end{array}$ & $\begin{array}{l}\text { Cor. } \\
\text { Pres } \\
\text { (kPa) }\end{array}$ & $\begin{array}{l}\text { Frict. } \\
\text { Work } \\
\text { (J/kg) }\end{array}$ \\
\hline $\begin{array}{l}\text { From: A } \\
\text { To: } \quad \text { B } \\
\end{array}$ & & & & & \begin{tabular}{|c|}
- \\
288.831 \\
\end{tabular} & 0.028 & 72.378 & 209.25 \\
\hline $\begin{array}{ll}\text { From: } \\
\text { To: } & \text { C } \\
\end{array}$ & & & & & 289.099 & 0.018 & 70.773 & \\
\hline $\begin{array}{l}\text { From: C } \\
\text { To: } \quad \text { D }\end{array}$ & & & & & 289.352 & 0.000 & 68.630 & $\begin{array}{r}- \\
-325.785 \\
\end{array}$ \\
\hline $\begin{array}{l}\text { From: } A \\
\text { To: } \quad D\end{array}$ & 286.15 & $\begin{array}{l}1163.3869 \\
1461.8898\end{array}$ & $\begin{array}{l}0.0101652 \\
0.0135602\end{array}$ & $\begin{array}{l}288.796 \\
289.374\end{array}$ & 289.085 & - & $\begin{array}{r}- \\
72.396\end{array}$ & 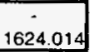 \\
\hline
\end{tabular}

Table 6: Barometer Survey Data Reduction Calculations
The data was reduced using McPherson's method of a direct application of the steady flow energy equation.

\begin{tabular}{|c|c|c|c|c|}
\hline \multicolumn{5}{|c|}{ BAROMETER SURVEY OUTPUT } \\
\hline Location & $\begin{array}{l}\text { Density } \\
\left(\mathrm{kg} / \mathrm{m}^{3}\right)\end{array}$ & \begin{tabular}{|l|} 
Specific \\
Volume \\
$\left(\mathrm{m}^{3} / \mathrm{kg}\right)$
\end{tabular} & $\begin{array}{c}\text { Frictional } \\
\text { Pressure Drop } \\
\text { (Pa) }\end{array}$ & $\begin{array}{c}\text { Frictional } \\
\text { Pressure Drop } \\
\text { (milli-in w.g.) }\end{array}$ \\
\hline 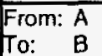 & $\begin{array}{l}0.875 \\
0.862 \\
\end{array}$ & $\begin{array}{l}1.142 \\
1.160 \\
\end{array}$ & 181.8 & 730 \\
\hline $\begin{array}{l}\text { From: } \mathrm{B} \\
\text { To: } \quad \mathrm{C}\end{array}$ & $\begin{array}{l}0.862 \\
0.827\end{array}$ & $\begin{array}{l}1.160 \\
1.209\end{array}$ & 1457.2 & 5850 \\
\hline $\begin{array}{l}\text { From: } \mathrm{C} \\
\mathrm{To:} \quad \mathrm{D}\end{array}$ & $\begin{array}{l}0.827 \\
0.827\end{array}$ & $\begin{array}{l}1.209 \\
1.209 \\
\end{array}$ & -269.5 & -1082 \\
\hline $\begin{array}{l}\text { From: } \begin{array}{l}\text { A } \\
\text { To: } \quad \text { D }\end{array}\end{array}$ & $\begin{array}{l}0.875 \\
0.827\end{array}$ & $\begin{array}{l}1.142 \\
1.209\end{array}$ & 1382.6 & 5551 \\
\hline
\end{tabular}

Table 7: Barometer Survey Results

Table 8 shows a comparison between the two measurement techniques for this portion of the survey. As can be seen from the comparison one of the measurements (portal to end of exhaust level) compares very closely between the two measurement techniques. However, the rest of the measurements compare very poorly. In the case of measurement stations $\mathrm{C}$ and $\mathrm{D}$ the barometer reduction came out in the negative indicating that the air would be flowing opposite the direction of presentation (from D to $C$ ) which is incorrect as personnel in the drift verified the direction of airflow from $\mathrm{C}$ to $\mathrm{D}$. The substantial differences between the two measurement techniques could have be resolved by taking additional or redundant barometric measurements. However, these differences were discovered during data reduction done away from the mine and would have necessitated shipping the barometers back to the mine and having mine personnel re-survey that portion of the mine. There are many variables with regards to the barometric survey that could have introduced error into the measurements. The most likely cause of the error would be with regards to the elevations measured by the mine surveyors. This is usually the weak link in the barometric survey as airway geometry changes with time due to ground movements, sloughage, milling and mucking of floor/sill, and roof falls.

\begin{tabular}{|c|c|c|}
\hline \multicolumn{3}{|c|}{ BAROMETER/GAUGE \& TUBE COMPARISON } \\
\hline Location & $\begin{array}{c}\text { Frictional } \\
\text { Pressure Drop } \\
\text { (Barometric Method) } \\
\text { (milli-in w.g.) }\end{array}$ & $\begin{array}{c}\text { Frictional } \\
\text { Pressure Drop } \\
\text { (Gauge and Tube Method) } \\
\text { (milli-in w.g.) }\end{array}$ \\
\hline $\begin{array}{ll}\text { From: } & \text { A } \\
\text { To: } & \text { B }\end{array}$ & 730 & 1252 \\
\hline $\begin{array}{ll}\text { From: } & \text { B } \\
\text { To: } & \text { C } \\
\end{array}$ & 5850 & 3379 \\
\hline $\begin{array}{l}\text { From: C } \\
\text { To: } \quad \text { D }\end{array}$ & -1082 & 964 \\
\hline $\begin{array}{ll}\text { From: } & \text { A } \\
\text { To: } & \text { D }\end{array}$ & 5551 & 5595 \\
\hline
\end{tabular}

Table 8: Comparison of Survey Results

Although the gauge and tube measurements in this example are not shown in a loop so closure can not be determined, the magnitude of gauge and tube measurements seem appropriate. During the survey the manometer stabilized around a (fairly) steady 
value which tends to lend confidence to the measurement. The gauge and tube measurements were used with other pressure measurements to determine closure, but that is outside the scope of this example.

\section{CONCLUSIONS}

Based upon the performance of many pressure surveys in both metal mines and coal mines the gauge and tube technique is more preferable than the barometric pressure technique. Each technique is applicable for certain aspects of a pressure survey, but for general measurements the gauge and tube method provides for more rapid evaluation and quite possibly more accurate results. Although a "basic" barometric pressure survey can be accomplished faster than a gauge and tube survey, once the necessary back-up or redundant barometric measurements are taken into consideration the measurement time difference is not quite so great. The gauge and tube method would be much more preferable than the barometric method for discrete measurements such as those required for friction factor determination. A brief comparison between the barometric, and gauge and tube methods is presented in Table 9.
When evaluating gob areas, abandoned areas, substantial lengths of shafts (greater than $2000 \mathrm{ft}$ ), black box models, or areas of a mine not safe to travel through, a barometric survey would be preferable over a gauge and tube survey.

Each survey method has a purpose and a preferred application. Prior to conducting a ventilation survey the pressure portion must be planned and the various methods chosen according to their applicability. There is no single "one size fits all" methodology, but rather a combination of methods should be incorporated into the overall survey plan.

\section{REFERENCES}

Hinsley, F.B. 1962. "The assessment of Energy and Pressure Losses Due to Airflow in Shafts, Airways, and Mine Circuits", Mining Engineering. Vol: 121, pp. 761-777.

McPherson, M.J. 1993. Subsurface Ventilation and Environmental Engineering. New York, New York: Chapman \& Hall.

Burrows J. et al 1989. Environmental Engineering in South African Mines. The Mine Ventilation Society of South Africa.

Hall C.J. 1981. Mine Ventilation Engineering. Society of Mining Engineers of The American Institute of Mining, Metallurgical and Petroleum Engineers, Inc. New York, New York

\begin{tabular}{|c|c|c|c|}
\hline \multicolumn{2}{|c|}{ Barometric Method } & \multicolumn{2}{|c|}{ Gauge and Tube Method } \\
\hline Advantage & Deficiency & Advantage & Deficiency \\
\hline requires minimal personnel & $\begin{array}{l}\text { relies on more than a single } \\
\text { pressure measurement } \\
\text { (velocity, elevation, } \\
\text { psychrometric) }\end{array}$ & $\begin{array}{l}\text { instantaneous pressure } \\
\text { measurement }\end{array}$ & $\begin{array}{l}\text { Travel must be accessible } \\
\text { between the two } \\
\text { measurement stations }\end{array}$ \\
\hline $\begin{array}{l}\text { establishes density at each } \\
\text { point }\end{array}$ & $\begin{array}{l}\text { data reduction is not done in } \\
\text { the field, erroneous } \\
\text { measurements are not } \\
\text { easily identified during the } \\
\text { survey }\end{array}$ & $\begin{array}{l}\text { closure determined in the } \\
\text { field }\end{array}$ & $\begin{array}{l}\text { measurements take time } \\
\text { as tube must be moved } \\
\text { between station locations }\end{array}$ \\
\hline rapid measurement & lengthy data reduction & higher accuracy & requires experience \\
\hline $\begin{array}{l}\text { travel between } \\
\text { measurement stations not } \\
\text { required (gob } \\
\text { measurements, abandoned } \\
\text { areas, black box models) }\end{array}$ & & $\begin{array}{l}\text { relies on only one } \\
\text { measurement (pressure) }\end{array}$ & $\begin{array}{l}\text { requires accurate digital } \\
\text { manometer for best } \\
\text { results }\end{array}$ \\
\hline
\end{tabular}

Table 9: Brief Comparison of Methods 